\title{
TERRITÓRIOS CAMPONESES NO MUNICÍPIO DE PARANÃ
}

\author{
(TO): luta e resistência da comunidade Angical
}

\section{TERRITORIOS CAMPESINOS EN EL MUNICIPIO DE PARANÃ} (TO): lucha y resistencia de la comunidad Angical

\author{
Silvaldo Quirino Tavares \\ Universidade Federal do Tocantins. Porto Nacional, TO, Brasil. \\ silvaldo@mail.uft.edu.br \\ Marcileia Oliveira Bispo \\ Universidade Federal do Tocantins. Porto Nacional, TO, Brasil. \\ marcileia@uft.edu.br
}

\section{Resumo}

Os camponeses, ao produzirem na terra, estabelecem um conjunto de relações sociais que apresentam características próprias. Neste sentido,- a formação socioespaciale de uma comunidade camponesa envolve uma série de relações que ocorrem ao longo do tempo, cujas práticas camponesas se consolidam e produzem novos arranjos. Isso ocorre por meio da consolidação do modo de vida intrínseco à classe em lugares onde formam territórios por intermédio da conquista e resistência. Desse modo, o objetivo principal deste trabalho foi analisar o processo de formação territorial e os elementos socioespaciais de resistência da comunidade Angical em Paranã (TO), frente às adversidades presentes na comunidade, por meio da análise de documentos, trabalho de campo, uso de entrevista semiestruturada e relatos orais. Observou-se que a existência e resistência do campesinato em Paranã se efetiva muito mais pelo protagonismo dos camponeses diante da necessidade de acesso e permanência na terra, que pelas possibilidades de reprodução social que as relações presentes no campo garantem, como também que o processo de formação e a permanência da comunidade Angical em Paranã, envolvem questões específicas de luta e resistência.

Palavras-chaves: Território. Camponês. Luta. Resistência. Comunidade Angical.

\section{Resumen}

Los campesinos, al producir en la tierra, establecen un conjunto de relaciones sociales que tienen sus propias características. En este sentido, la formación socioespaciale de una comunidad campesina involucra una serie de relaciones que ocurren con el tiempo, cuyas prácticas campesinas se consolidan y producen nuevos arreglos. Esto ocurre al consolidar la forma de vida intrínseca de clase en lugares donde forman territorios a través de la conquista y la resistencia. Así, el objetivo principal de este trabajo fue analizar el proceso de formación territorial y los elementos socioespaciales de resistencia de la comunidad Angical en Paranã (TO), frente a las adversidades presentes en la comunidad, a través del análisis de documentos, trabajo de campo., uso de entrevistas semiestructuradas e informes orales. Se observó que la existencia y resistencia del campesinado en Paranã es 
mucho más efectiva debido al protagonismo de los campesinos en vista de la necesidad de acceso y permanencia en la tierra, que por las posibilidades de reproducción social que garantizan las relaciones presentes en el campo, así como El proceso de formación y la permanencia de la Comunidad Angical en Paranã involucran temas específicos de lucha y resistencia.

Palavras clave: Territorio. Campesino. Lucha. Resistencia. Comunidad Angical.

\section{Introdução}

O modo de vida camponês é caracterizado tanto pela sua história de luta pelo acesso à terra quanto pelas especificidades de suas práticas produtivas e culturais. A ligação com a terra está na base da reprodução social. Esse necessário vínculo, como ressalta Oliveira (2007), tem sido motivo de muitos embates frente à expropriação causada pelo capitalismo. Em razão disso, o processo migratório tornou-se alternativo para aqueles que buscam o acesso a uma área de terra para produzir.

De acordo com Martins (2004) o movimento camponês no Brasil já passou por momentos de grande expressão e momentos de repressão pelos interesses dominantes. Durante a Ditadura Civil-Militar (1964-1985), por exemplo, a ações dos trabalhadores sem - terra ficaram limitadas devido a repressão aos movimentos sociais ser mais intensa. Somente após esse período houve abertura para o "amplo território da liberdade, da democracia e da sociedade como agente do querer histórico". Os movimentos começam ganhar força para suas reivindicações

Neste processo, o direito de acesso à terra por meio de políticas públicas de desconcentração fundiária tem sido objetivo dos trabalhadores rurais. Entretanto, de acordo com Martins (2004), a reforma agrária tem sido uma discussão repleta de equívocos interpretativos, sendo alvo de muitas opiniões irrefletidas. Segundo o autor, esses conflitos de ideias são impasses para os avanços no processo necessário para a resolução dos problemas sociais ligados a questão fundiária.

É importante ressaltar que muito antes da Ditadura Civil-Militar os conflitos pela terra já eram intensos no Brasil. Conforme Guimarães (1988), no caso da antiga Região Centro Norte de Goiás, onde hoje compreende parte das Regiões Sul e Sudeste do Estado do Tocantins, os conflitos ganharam força nos anos 1950 e 1960. A referida autora mostra que em algumas cidades como Trombas, Formoso, Gurupi e Natividade a situação foi 
mais tensa. Exemplo disso foram os movimentos de Formoso e Trombas ${ }^{1}$ ocorridos na década de 1950. Já em outras cidades que estão na mesma região, como o caso de Paranã, os conflitos foram menos expressivos, mas havendo, também, ações violentas contra camponeses.

Neste espaço de luta, perdurado por um longo tempo, as práticas camponesas se consolidam e produzem novos arranjos. Isso ocorre por meio da consolidação do modo vida intrínseco à classe em lugares onde formam territórios por meio da conquista e resistência. Estes espaços adquirem especificidades conforme o modo de produção camponês, o qual, de acordo com Oliveira (2007), está baseado em relações não capitalistas, as quais não têm a circulação de mercadorias e de dinheiro como elemento básico.

No entendimento de Moraes (1999), toda produção engloba uma série de relações envolvendo diferentes atores em diferentes escalas. São as relações sociais de produção, as quais variam de complexidade conforme o nível das forças produtivas. É nestas relações que ocorre o processo de formação socioespacial das comunidades camponesas.

De acordo com Santos, (1982) a formação socioespacial, no âmbito geral, engloba práticas sociais ligadas ao modo de produção dominante. Ele explica que as ações humanas em diferentes escalas produzem, em um tempo histórico, as formas e processos espaciais. Assim, o modo de vida estabelecido pelas práticas locais de um determinado grupo social é delineado pelos processos históricos que influenciam a continuidade da reprodução espacial, conforme as especificidades das relações existentes.

Neste contexto, o universo de relações da reprodução social e do modo de produção camponês apresentam características que distinguem das relações de produção típicas do capitalismo. Um elemento dessas relações é a produção focada no próprio consumo da família, tendo a venda do excedente como meio para adquirir as mercadorias que não produz. Considerando estes aspectos, desenvolvemos a presente pesquisa na comunidade Angical, em Paranã (TO), que é formada por um grupo de camponeses que residem resistindo às forças contrárias à sua classe.

\footnotetext{
${ }^{1}$ De acordo com Cunha (1995) esse movimento camponês ocorrido em Formoso e Trombas era voltado à luta pela posse da terra, mas com apoio da política revolucionário do Partido Comunista Brasileiro (PCB). A resistência de um grande número de posseiros frente às intervenções violenta de fazendeiros que tentava tomar posse das terras acabou em um conflito armado no campo. Este conflito teve grande repercussão na região e na trajetória de luta dos camponeses da região norte de Goiás.
} 
De acordo com o IBGE (2010), Paranã é uma cidade histórica do Tocantins situada na Região Sudeste do estado. Foi elevada à categoria de cidade em 05 de outubro de1857. É o segundo município em área territorial no Tocantins tendo $11.260 .216 \mathrm{~km}^{2}$, conforme o IBGE (2010). Conforme o mesmo órgão, o município tem uma população de 10.338 habitantes, com densidade demográfica de $0,92 \mathrm{hab} / \mathrm{km}^{2}$, sendo $54,3 \%$ residentes no campo. Tem como principal atividade econômica a criação de gado (pecuária). O cultivo de vegetais (agricultura) é menos significativo, mesmo assumindo grande importância.

Já a comunidade Angical é situada na parte centro-leste do município na latitude $12^{\circ} 32^{\prime} 15^{\prime} \mathrm{S}$ e longitude $47^{\circ} 35^{\prime} 05^{\prime \prime} \mathrm{W}$ (Figura 1). Nela manifesta as principais características da organização do espaço agrário no município de Paranã. Presencia-se as realidades físico-ambientais e sociais, englobando o processo de reprodução do espaço, os conflitos territoriais e as principais demandas socioeconômicas do campo.

Figura 1- Mapa de localização da área da pesquisa

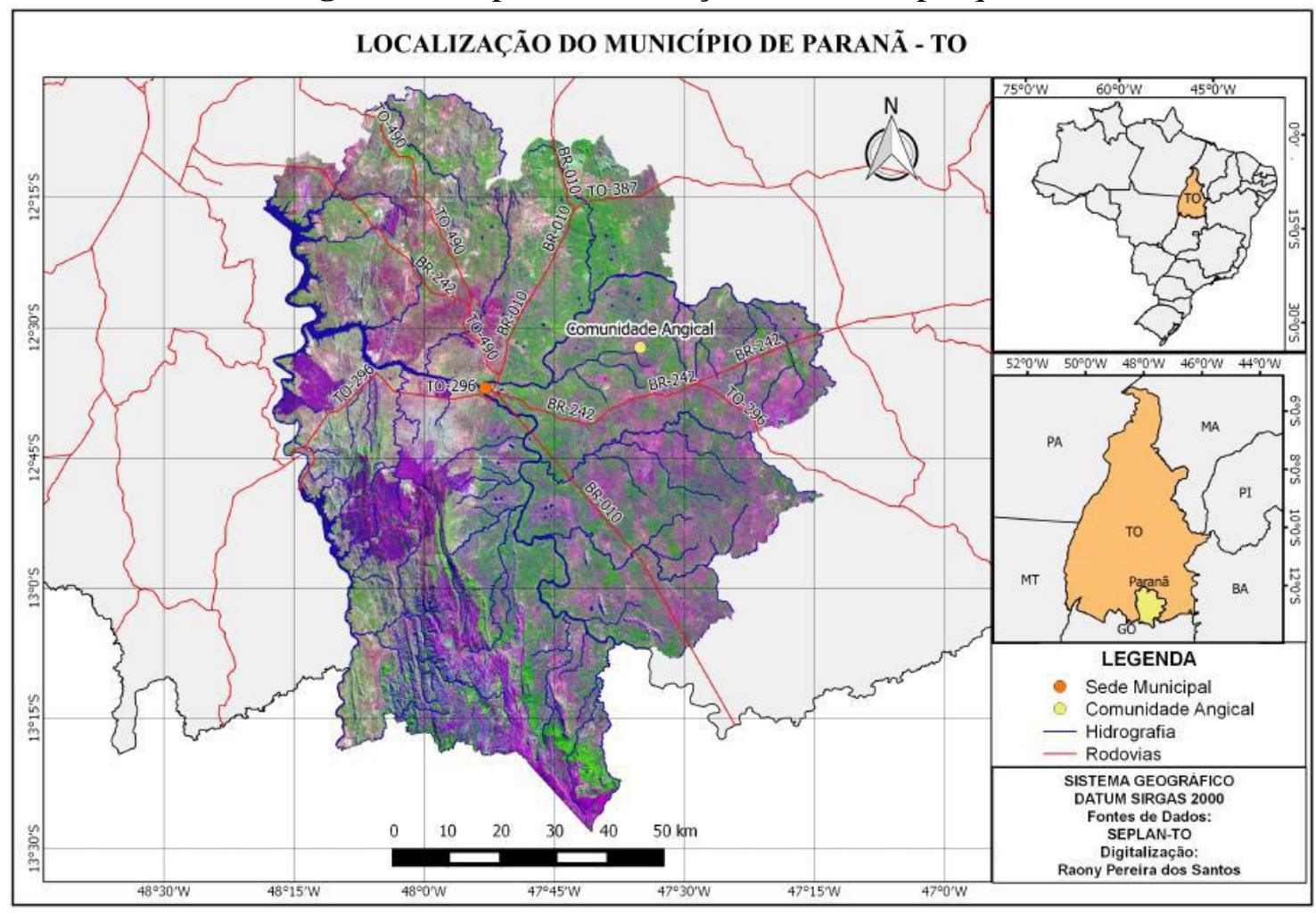

Fonte: Autor. TAVARES, 2017.

Dentro deste cenário os conflitos territoriais têm sido sérios problemas para a comunidade em estudo. Tais conflitos estão ligados principalmente à questão da posse da terra, tendo os camponeses posseiros de um lado e fazendeiros que dizem ser donos da 
área de outro. Em decorrência desses conflitos surgem outros como a questão do acesso água do rio Palma que o único perene e de grande porte próximo da comunidade, mas com a fazenda Frade bloqueando o acesso para muitas famílias.

Nesse contexto os camponeses têm lidado com sérias dificuldades relacionadas aos conflitos territoriais. Além disso lidam com outras questões estruturais presentes no campo em Paranã. Estes problemas têm se intensificado nas últimas três décadas, porém as famílias têm resistido e permanecem no território. Desse modo é importante entender como estes conflitos tem ocorrido e quais tem sido os meios de resistência da comunidade.

Considerando estes aspectos, este trabalho teve como objetivo analisar o processo de formação territorial e os elementos socioespaciais de resistência da comunidade Angical frente às adversidades sociais nela presentes. Pretendeu-se também interpretar a organização espacial da comunidade Angical, e ainda discutir os elementos da resistência camponesa diante das contradições das relações sociais existentes no campo, no município de Paranã.

Buscando alcançar tais objetivos, o procedimento inicial para o desenvolvimento deste trabalho, oriundo de uma pesquisa de mestrado da Universidade Federal do Tocantins (UFT), consistiu na revisão bibliográfica através de diversas fontes textuais da literatura inerente ao tema. Além disso, ocorreu a análise de documentos de instituições públicas federais, estaduais e municipais. Este levantamento tem como finalidade situar a problemática na discussão desenvolvida pelos principais conceitos a serem operacionalizados na elaboração do presente texto.

Outra etapa da pesquisa foi o trabalho de campo, realizado em 2017, após aprovação do projeto de pesquisa pelo Comitê de Ética em Pesquisa (CEP) da UFT. Nessa fase ocorreu um contato direto com o ambiente de pesquisa, priorizando o diálogo com os camponeses que são os principais participantes da pesquisa. Com isso, nesta etapa foi realizou-se um estudo de caso na comunidade Angical, através de entrevistas semiestruturadas, com uso de gravador, com os moradores mais antigos que concordaram.

Como garantias éticas aos participantes, todos foram esclarecidos da liberdade de participação como voluntários. O tratamento dos dados e gravações ocorreram mantendo o sigilo das informações disponibilizadas ao pesquisador. Com isso foram usadas apenas as siglas dos nomes dos entrevistados no presente trabalho. 
Por meio de todos estes procedimentos foi possível produzir este artigo, o qual está estruturado em dois tópicos, além da introdução e considerações finais. No primeiro tópico discute-se o modo capitalista de produção e a resistência camponesa no Tocantins. No segundo tratamos da territorialização e os conflitos agrários na comunidade Angical.

\section{Modo capitalista de produção e resistência camponesa no Tocantins}

O incremento do modo capitalista de produção no campo tocantinense provocou a expansão do capital neste espaço causando muitas consequências negativas no que refere à condição de vida das populações rurais. Isto ocorre porque este sistema não é “[...] circunscrito apenas à produção imediata, mas também à circulação de mercadorias, portanto, inclui também a troca de mercadorias por dinheiro e, obviamente, de dinheiro por mercadorias." (OLIVEIRA, 2007, p. 20). Assim, a reprodução capitalista requer relações econômicas exploradoras e, consequentemente, intensificadoras dos conflitos territoriais agrários e da expropriação territorial de povos e comunidade tradicionais em geral. Em resposta a isso, a luta pela terra a e resistência às forças destrutivas destes territórios se fazem necessárias, como ocorre no campesinato.

\footnotetext{
Assim, esses camponeses não são entraves ao desenvolvimento das forças produtivas, impedindo o desenvolvimento do capitalismo no campo; ao contrário, eles praticamente nunca tiveram acesso à terra, sendo, pois desterrados, "sem - terra", que lutam para conseguir o acesso à terra. É no interior destas contradições que têm surgido os movimentos sociais de luta pela terra, e, com ela, os conflitos, a violência. (OLIVEIRA, 2001a, p. 187).
}

Estas relações contraditórias estão presentes no Estado do Tocantins, em que as forças que movem a expansão do capitalismo são munidas de intencionalidades exploratórias, as quais ignoram a necessidade do desenvolvimento local. Um exemplo disso é a construção da BR-153, que Miranda e Lira (2015) apontam como uma iniciativa do governo federal com papel fundamental na abertura da fronteira agrícola no antigo norte do Estado de Goiás, atual Estado do Tocantins. Neste contexto, a finalidade das articulações políticas, normalmente, é atender interesses econômicos de nível escalar mais abrangente, tendo como prioridade o posicionamento do país no cenário internacional por meio das relações com o capital estrangeiro. 
Dessa forma, os programas de desenvolvimento implementados, de iniciativa nacional ou estadual, não levam em consideração as especificidades socioculturais regionais existentes. Para facilitar o avanço dos projetos econômicos seus impactos negativos "[...] foram transformados em questões técnicas, passíveis de serem contornadas mediante a aliança entre capital, burocracia e ciência”. (RIBEIRO, 2005, p. 181). Entretanto, as populações impactadas não entram nesta negociação, restando a elas o enfrentamento por meio de lutas organizadas pela própria classe.

É importante considerarmos que, por se tratar de uma região de transição, o processo de expansão da fronteira agrícola, ocorrido no Tocantins, está ligado tanto às políticas desenvolvimentistas implementadas com foco no cerrado brasileiro quanto às direcionadas para a Amazônia Legal. Neste aspecto, o estado se encontra numa condição de convergência regional sendo contemplado por duas frentes de desenvolvimento econômico de caráter nacional. É mais um motivo da intensa disputa territorial.

É pertinente considerar que "no Cerrado talvez mais do que em qualquer outra região, a modernização da agricultura foi um empreendimento cujos custos ambientais, sociais e culturais foram socializados e os lucros concentrados em poucas mãos”. (RIBEIRO, 2005, p. 211). Na Amazônia Legal as intenções são semelhantes, quanto à expansão do capital agrário. Santos, (2015) argumenta que as políticas territoriais implantadas nessa região têm como uma das suas metas a diminuição dos conflitos agrários do Sul do Brasil. Isto significa que a abertura da nova fronteira agrícola não leva em consideração os novos conflitos territoriais que causariam. Desse modo as forças expropriadoras no campo tocantinense são múltiplas e em muitos casos negligenciadas.

Além disso, o Tocantins está inteiramente inserido na área do Matopiba (Maranhão, Tocantins, Piauí, Bahia) recentemente "definida" para fins de investimentos do capital agrário no Brasil. Trata-se de mais uma iniciativa de cunho puramente econômico que amplia, de início, os conflitos territoriais nos estados membro. De acordo com Souza (2016), as diretrizes estabelecidas pelo Plano de Desenvolvimento Agrário (PDA) desta área estratégica do Brasil, são compostas de estratégias políticas voltadas ao incremento da competitividade no setor agrícola.

Souza (2016) aponta ainda que para viabilizar o PDA, o Estado investe em infraestrutura e pesquisas científicas, como as voltadas ao cultivo da soja no Cerrado realizadas pela Embrapa, que atendem os interesses das corporações e grandes 
investidores. Assim é lançada uma nova base para a alteração da realidade econômica, social e cultural nos estados e municípios abrangidos. Neste plano de "desenvolvimento" as populações do campo são negativamente impactadas de modo mais direto. Necessariamente entra em conflito com a expropriação gerada pelo capital rentista munido de apoio das políticas estatais. Essas políticas se efetivam por meio de discursos divergentes das intencionalidades, sem gerar os resultados propostos, como ocorre com a ideia de modernização que:

[...] representou para a agricultura uma nova interação entre setores da economia brasileira; embora continuasse a participar como geradora de divisas pela exportação de parte considerável de sua produção, ela agora teria uma crescente integração subordinada com o setor industrial financeiro. A adoção do todo o chamado pacote tecnológico da Revolução Verde, que incluía o uso de máquinas, equipamentos, fertilizantes, agrotóxicos, sementes, matrizes melhoradoras etc., possibilitou o aumento da produção não mais pela expansão da área explorada, mas pelo incremento da produtividade. (RIBEIRO, 2005, p.72).

Estas propostas da Revolução Verde de $1970^{2}$ possibilitaram muito mais a entrada do capital agrário em novos territórios, que a diminuição da demanda por terras agricultáveis, como seria esperado. A necessidade de grandes áreas de terra desocupadas para a produção agrícola em grande escala tem crescido e como fator gerador de violência contra as populações que residem no campo tocantinense. $\mathrm{O}$ jogo de interesse entre $\mathrm{o}$ poder econômico e o político no Brasil tem permitido articulações massacrantes para possibilitar a reprodução capitalista no campo. Nestes aspectos, o Tocantins é visto como:

[...] uma fronteira agrícola e econômica no interior do Brasil, que vem sendo utilizada a partir de projetos implementados pelo governo em vários setores (agricultura, construção de usinas de geração de energia elétrica e outros investimentos), que visam integrar o estado e sua economia ao contexto da lógica do modelo de desenvolvimento nacional. (OLIVEIRA, 2016, p. 209).

Diante disso, a aliança entre o Estado e o capital permite que os mesmos espaços agrários sejam concorridos de forma mais intensa, o que exige um novo foco em outras áreas de exploração a procura de maiores possibilidades de lucro. Além disso, a sujeição da renda da terra ao capital é crescente sendo "[...] o mecanismo básico do processo de expansão do capital no campo. Esse processo se dá quer pela compra e venda da terra, quer pela subordinação da produção camponesa". (OLIVEIRA, 2007, p. 12). Dessa

\footnotetext{
${ }^{2}$ Processo de modernização da agricultura ocorrido em diversas partes do mundo com o uso intenso de agrotóxico e fertilizantes sintéticos aumentando a produtividade agrícola, mas provocando problemas de ordem social e ambiental.
} 
forma, se em um primeiro momento as vantagens estavam na potencialidade produtiva da terra, agora o preço dela ganha grande importância, de modo que onde o preço é menor o capital avança mais.

Neste cenário, é evidente que a luta das comunidades tradicionais para resistir às forças econômicas tende a se tornar mais tensa, visto que grande parte delas se encontra em áreas que antes não eram muito concorridas pelo agronegócio. A desterritorialização ocorre sustentada pelo poder político e econômico vigente e "[...] fornecem uma espécie de síntese do neocolonialismo e da violência que tem se abatido sobre as populações tradicionais nos países latino-americanos." (XAVIER, 2015, p.79). Em consequência, as diferentes comunidades rurais precisam lançar mão dos mecanismos de resistência camponesa na luta pelo acesso e permanência na terra.

De acordo com Oliveira (2016) a luta camponesa no Tocantins tem seu surgimento influenciado por movimentos que ocorrem ainda no antigo norte de Goiás. Ele cita o exemplo das ações das Ligas Camponesas na década de 1960 que organizaram os movimentos de Formoso e Trombas, dando uma balançada nas grandes propriedades rurais da região. Foram dois episódios de luta camponesas marcantes e que nortearam as gerações posteriores sobre a necessidade da resistência à formação irregular de latifúndios e à expropriação camponesa.

Um fato preocupante neste cenário histórico e nos processos atuais é que, normalmente, as tensões envolvendo camponeses e fazendeiros partem da existência de apropriação ilegal de grandes áreas de terra. "A grilagem e o apossamento foi um dos meios utilizados pela burguesia agrária para se apropriar de largas extensões de terras no Brasil em todas as regiões.” (MIRANDA; LIRA, 2015, p. 322). Esta realidade faz parte da estrutura fundiária do Tocantins, onde a existência de latifúndios irregulares é alarmante. Este fato é evidente no Diagnóstico Fundiário do Município de Paranã (2010), o qual mostra que 56\% das terras do município terras são irregulares. Isto leva os trabalhadores rurais destituídos de terras e conscientes da presente contradição, estar em luta constante.

Dado o problema da questão agrária, gerado principalmente pelos latifundiários contra os camponeses e a necessidade de lutar contra essa contradição, fez com que os movimentos Sindicais e Sociais de natureza afins comprometido com a reforma agrária, se mobilizassem e lutassem. Dessa forma os movimentos Sociais e Sindicais de luta pela terra, presente no Estado do Tocantins se articularam, se organizaram com a finalidade de entrar na luta 
e travar o enfrentamento ora pelas vias legais ou ora pelas vias legitimas (ocupações não autorizadas), com ações pacificas e enérgicas. (BARBOSA, 2016, p. 69).

Neste contexto, as lutas ocorrem tendo dois focos: sendo um voltado à resistência das forças capitalistas nos territórios camponeses já constituídos e outro direcionado à conquista da terra por aqueles que não a possui. Oliveira (2016) aponta que como resultado da luta camponesa o número de assentamentos tem multiplicado no Tocantins mas deixa claro que isso tem sido fruto de algumas ações pontuais do estado e da pressão dos movimentos sociais sobre as ações do poder público. Dessa forma, a existência de acampamentos organizados pelos movimentos sociais, sobretudo o MST, reivindicando o avanço da Reforma Agrária é constante no Tocantins.

Outra ação comum no campo da luta camponesa é a ocupação de terras improdutivas do Estado sob “domínio" irregular de latifundiários. É uma iniciativa que pode ter resultados distintos em diferentes confrontos e negociações. Dependendo da articulação camponesa e do posicionamento do poder público pode ser que ocorra um despejo forçado acompanhado de violência. Ou, na melhor das hipóteses, pode ocorrer a conquista por meio de direito de posse ou formação de assentamentos. Entretanto, a violência, em diferentes aspectos, tem sido o desfecho de muitos casos, pois o Tocantins

[...] se destaca no ranking de violência do poder público no quesito de prisões. No ranking de violência do poder privado, no quesito assassinato, o Tocantins ocupa o $5^{\circ}$ lugar. No quesito de prisões, o Tocantins se colocar em primeiro lugar nos remete a pensar na tese de que o governo estadual, do período de 2003, quando foram coletados os dados sobre o mapa da violência, foi altamente autoritário e repressor dos movimentos sociais no campo. (SANTOS, 2014, p. 213).

Nestes aspectos, o posicionamento do poder público, nas unidades federativas, pode ser visto como uma força de repúdio à resistência da classe camponesa, a qual bate de frente com avanço do capital rentista expropriador e com a existência de latifúndios improdutivos. É uma reprodução da esfera nacional de poder em que o Estado como regulador das ações políticas e econômicas é contraditório aos interesses sociais emergentes. E isto faz parte de um doloroso processo histórico:

Desde 1964, justamente em face dos impasses políticos resultantes da questão agrária, que levaram ao golpe, o Estado brasileiro criou um aparato institucional para administrar a questão fundiária, de modo que ela não comprometesse os planos nacionais de desenvolvimento que a têm como um dado secundário. (MARTINS, 2004, p. 09). 
Em decorrência deste mesmo posicionamento político presente no Tocantins, o avanço da Reforma Agrária ainda é muito incipiente, mesmo que alguns passos têm sido dados com a criação de assentamentos. Barbosa (2016) chega a conclusão que o fato do estado do Tocantins aderir uma política de desenvolvimento da agricultura capitalista impede o andamento da Reforma Agrária e, consequentemente, da agricultura camponesa. Nestes termos, na reprodução do modo de vida camponês, a formação e resistência territorial é uma questão de luta frente ao capital privado e as decisões contraditórias ou as negligências do poder público.

Diante destas contradições, os espaços de reprodução do modo de vida camponês se formam, muitas vezes, pela conquista oriunda do protagonismo da classe na luta pelos interesses sociais. As reivindicações dos movimentos organizados ou, às vezes, de grupos isolados colocam em pauta a necessidade de decisões e resolução dos conflitos. "Neste sentido, o Estado apresenta-se como espaço de "solução" para os problemas dos seguimentos de trabalhadores excluídos do sistema econômico, social, político e cultural." (OLIVEIRA, 2016, p. 208). A intervenção estatal, normalmente, ocorre para controlar as tensões das disputas territoriais. Entretanto, trata-se de um controle paliativo, em que na maioria das vezes, os camponeses têm seus interesses suprimidos.

Estes trabalhadores e camponeses sem terra sabem das histórias de luta para
conquistar e para manter um pedaço de terra, contadas por seus antepassados
e, embora saibam que historicamente o Estado tem sido incapaz de solucionar
os problemas fundiários, com os recursos legais sendo definidos pelos
poderosos em benefício próprio, não se cansam de lutar por transformações na
estrutura fundiária deste país. (OLIVEIRA, 2016, p. 209).

Neste contexto, há muitos casos em que as iniciativas camponesas, ocorrem fora das orientações jurídicas do Estado, mas dentro da consciência da classe sobre realidade fundiária das terras reivindicadas. Com isso, em casos de ocupações de terras devolutas improdutivas que se encontram sob "domínio" de grandes proprietários, de forma irregular, a resistência dos posseiros é grande. Eles fazem parte de uma "[...] parcela dos camponeses sem terra, que vêm historicamente lutando numa ponta contra a expropriação que os gera e, na outra, contra os jagunços, "gendarmes ${ }^{3}$ de plantão" dos latifundiários

\footnotetext{
${ }^{3}$ Em sentido amplo o termo “gendarmes' é referente à corporação militar. No texto citato trata-se de uma espécie de guarda que que atua na segurança de uma determinada área.
} 
especuladores e grileiros". (OLIVEIRA, 2001a, p.190). Assim, esta luta consciente ocorre em todas as regiões do país.

No caso do Tocantins não é diferente a situação dos posseiros. Faltando elementos legais para a desocupação das terras onde eles vivem, duas situações são possíveis: o uso da violência pelo poder privado e público contra estes camponeses ou permanência do grupo na área constituindo relações duradouras e se territorializando. Mas não se trata de uma territorialização integralmente pacífica. As tensões são constantes, mesmo nos casos em que os conflitos não chegam à estágio avançado com confrontos ou massacres.

A formação destes territórios camponeses, constituídos de posseiros, ocorre sem a intervenção do poder público, tendo algumas especificidades na trajetória de luta que só podem ser compreendidas mediante estudos de casos específicos. As forças que movem o surgimento destes grupos sociais e que permitem a permanência deles em uma determinada área de terra surgem de relações intrínsecas à referida classe. Entretanto, não se trata de elementos desligados das normativas jurídicas e políticas que abrangem a sociedade geral.

A condição de existência do modo de vida camponês no Brasil e no Tocantins, especificamente, abrange um campo de luta no qual o poder político e econômico, assumem papel contraditório. Com isso, a constituição de uma comunidade camponesa e formação do seu território pode se efetuar mesmo havendo negligências do poder público quanto a esta questão. Nestes aspectos as condições de cidadania e reprodução da dignidade humana, na comunidade Angical, são construídas dentro das experiências históricas e contemporâneas do grupo social, as quais permitem sua territorialização.

\section{A territorialização e os conflitos agrários na comunidade Angical - Paranã-TO}

O processo de formação territorial da comunidade Angical tem como ponto de partida a chegada dos primeiros camponeses na área, na primeira metade do século XX, à procura de terra produtiva. A partir desse momento houve o crescimento gradativo do número de famílias que chegou a 43 até meados de 2017. Assim a comunidade Angical localiza-se nas áreas que envolve três grandes fazendas. Tendo como base, também, o Diagnóstico Fundiário do Município de Paranã (2010), identificamos que das quarenta e três (43) das famílias, vinte e oitos (28) estão na área referente à Fazenda Fênix, que foi 
um novo nome dado pelo Fazendeiro que diz ser dono da área, a qual desde o início da comunidade é conhecida como Angical. Dentre as demais famílias oito (8) são posseiras na Fazenda Frade e sete (7) na Fazenda Torra.

O que chama mais atenção na área em conflito com a Fazenda Fênix é o fato de ela ser basicamente toda ocupada pela comunidade Angical que é um território formado desde início do século XX. É por isso que nesta área a situação é mais tensa, sobretudo quanto a situação das residências mais dispersas e que ocupam áreas maiores. De acordo com o depoimento de um dos donos, essas posses de áreas maiores dentro da comunidade, são frutos da compra de outras posses que foram vendidas por posseiros anteriores.

A segunda área da comunidade em maior conflito territorial é a que abrange a Fazenda Frade. Nesta o número de família é bem menor, entretanto, o fato de a referida fazenda estar entre a comunidade e o Rio Palma (oito quilômetros da comunidade) intensifica as tensões por ser uma barreira de acesso a água para os camponeses. Apenas algumas famílias tinham acesso ao referido rio no período da pesquisa, mas sendo ameaçadas de bloqueio. Com isso, o conflito com a Fazenda Frade está ligado à permanência na terra e o acesso à água superficial disponível no Rio Palma.

Essa situação não é tranquila com os camponeses que são posseiros na Fazenda Torra, pois é uma área também em conflito com fazendeiros. Trata-se de duas situações em termo do tempo em que ocorreu a ocupação desta área, sendo algumas famílias residentes há décadas e outras mais recentes, com menos de uma década. Entretanto, o campo de luta é único entre todos esses camponeses, tendo como referência espacial a comunidade Angical.

Partimos do entendimento de que a formação territorial está ligada à existência de relações entre os sujeitos que compõe o grupo social, sendo uma reprodução do espaço por meio das experiências históricas e presentes. O território, nesta ótica, vai além do poder de dominação, abrangendo também a consolidação de um modo de vida na produção do espaço geográfico. É fundamental considerar que a "formação de um território dá às pessoas que nele habitam a consciência de sua participação, provocando o sentido da territorialidade que, de forma objetiva, cria uma consciência de confraternização entre elas". (ANDRADE, 2004, p. 20). Dessa forma, percebe-se que os aspectos relacionados à identidade dos sujeitos também assumem centralidade por meio das ações coletivas do grupo. 
De acordo com a nossa perspectiva, a territorialidade adquire um valor bem particular, pois reflete a multidimensionalidade do "vivido" territorial pelos membros de uma coletividade, pelas sociedades em geral. Os homens "vivem", ao mesmo tempo, o processo territorial e o produto territorial por intermédio de um sistema de relações existenciais e/ou produtivistas. (RAFFESTIN, 1993, p. 158).

Neste contexto, a comunidade Angical tem uma formação territorial peculiar no que diz respeito à trajetória de luta das famílias que ali residem. Tendo a formação territorial iniciada por camponeses posseiros no início do século $\mathrm{XX}$, passou por momentos distintos de resistências que reporta aos diferentes momentos históricos da formação e exploração do território brasileiro. Se no início da formação territorial as primeiras famílias tinham como principal dificuldade o isolamento da área, com falta de estradas de acesso à sede municipal, esse cenário muda a partir de meado do século XX surgindo novas preocupações.

A criação de grandes fazendas e formação de latifúndios no município de Paranã é outro processo histórico que acentua a partir da segunda metade do século XX, momento em que as terras do município passam a ser apropriadas por investidores de outros estados, sobretudo de São Paulo. As formações de grandes propriedades surgem por diferentes vias e com distintas intencionalidades. Em algumas desenvolve a agropecuária extensiva. Em outras a terra é controlada apenas como uma reserva de valor. Essa realidade converge com o problema da concentração fundiária:

A concentração da propriedade da terra, nas mãos de grandes proprietários,
juntamente com a concentração das unidades de produção nas mãos de
pequenos agricultores, coloca-nos diante de uma situação de crise do regime
de propriedade no Brasil. Isso porque não obstante a crescente concentração
da propriedade, há, como vimos, ao mesmo tempo, um drástico crescimento
do trabalho familiar na agricultura. É nesse contexto que o aumento da
importância do trabalho familiar só pode ocorrer através de tensões e conflitos,
como resistência anticapitalista, como resistência à expropriação. (MARTINS,
1995, p. 143).

Diante disso, muitos posseiros no município de Paranã que até então não enfrentavam problemas de conflitos agrários, passam a serem alvos de expropriação territorial, tendo os grandes proprietários de terra com principais agentes do processo. A apropriação de grandes áreas de terra a baixo custo, por vias legais ou ilegais, tornou-se um campo de ação dos grandes fazendeiros. Esse cenário histórico transforma muitos 
camponeses que se consideravam donos de suas terras em posseiros ou atém mesmo expropriados definitivamente das áreas onde trabalhavam.

No caso da comunidade Angical esta expropriação não ocorreu pelo fato das famílias que ali residem terem resistido às tentativas de expulsão, como por exemplo, ameaças de fazendeiros que dizem serem donos das terras, mesmo sem apresentar documentos de regularização que comprove tal propriedade. De acordo com relatos de membros da comunidade, as pressões dos fazendeiros acontecem, mas não são recorrentes. Em razão disso, a permanência das famílias mais antigas e o surgimento de outras, normalmente descendentes, tem sido possível.

Partindo do pressuposto que com a chegada e adaptação houve um processo de territorialização do grupo, é importante entender como este processo ocorreu e como se encontra a questão territorial. Neste sentido, o conhecimento proveniente dos próprios membros da comunidade é fundamental. Compreender o processo histórico e o cenário presente requer o uso de saberes que vão além das discussões teóricas já sistematizadas sobre o assunto. É preciso aproximar da realidade empírica para identificar as experiências de lutas, conflitos e reprodução social do grupo.

A chegada das primeiras famílias de camponeses na comunidade Angical ocorreu no início do século XX. De acordo com as entrevistas realizadas (6 semiestruturadas e 19 formulários objetivos), a terra pertencia ao Estado e a principal dificuldade era adaptar com o relativo isolamento do local em relação sede municipal. O objetivo dos camponeses então, foi adaptar de acordo o modo de vida que trazia, tendo como objetivo a permanência e reprodução social naquela área.

De acordo com os depoimentos de idosos da comunidade, o primeiro morador da comunidade Angical foi o Senhor Felix, que trabalhou como vaqueiro, no início do século $\mathrm{XX}$, para criadores de gado que exploravam aquelas terras. Ele se fixou nesta terra após o fim da fazenda que ali existia e a partir daí o grupo começou crescer lentamente, de modo que todos os moradores mais antigos encontrados durante a pesquisa eram descendentes dele. Os entrevistados afirmaram que a primeira moradia foi direito de posse doado para o Senhor Felix, como herança do trabalho que prestou como vaqueiro ao Senhor Victor, que era o "dono" daquelas terras, até então. É uma situação difícil de compreender na íntegra, por falta de registros, entretanto é a forma como as pessoas que 
moram compreendem a origem da comunidade Angical. Uma das entrevistadas, de 72 anos, relata suas experiências iniciais na comunidade da seguinte forma:

\begin{abstract}
Quando eu cheguei pra aqui só tinha Abel e Petronília mais Neuzinho. Bertulina mais Celino, eles tinham aquela casa alí mas eles eram vaqueiros nas Craíbas. Depois é que eles voltaram pra aqui. Também as pessoas que tinham aqui era eles aí. E Neuzinho do outro lado, que eles vieram pra aqui rapazinho novo, sabe? Onde minha mãe convidou Sarafim. Ele morava no Bom Jesus. Falou: Sarafim vamos embora voltar pro Angical? Ele não quis. Ele era vaqueiro da velha Josa. Diz: Há cê não vai eu vou. Ela me contava isso milhares de vezes. Aí ela veio mais Neuzinho e Abel. Aí eles fizeram essa casa aí. Aí Neuzinho foi morar lá na sede velha do pai dele, que é aonde Loro tá. Que alí era a sede velha do meu sogro. Aí ela Petronília ficou aqui mais ele, Abel. E aí aqui ele casou e teve todos os filhos aqui. 16 filhos morando aqui. Só uma menina que meu pai panhou pra criar, mas ela estava desse tamanho assim, quando meu pai panhou. Mas criei todo mundo e aqui eu estou. E aqui ele foi enterrado. Ele morreu aqui e foi enterrado bem alí embaixo. Só tinha só Bertulina aí, depois é que foi espalhando, Domingo Vermelho pra acolá, Augusto pra acolá. E foi rendendo, né? Foi espalhando. Compoca Zacaria chegou fez um sitiozinho pra acolá. Já é mais afastado um pouco mais é tudo da região. A velha minha cunhada pra alí, a velha Eva. Tudo é parente tudo pertinho. Mas não tinha ninguém depois é que foi chegando. Foi chegando, agora olha o tanto de gente que já tem, né? (T.S.A., PESQUISA DE CAMPO, 2017).
\end{abstract}

Nessa fala da entrevistada T.S.A., percebe-se a forma como os primeiros moradores da comunidade chegaram. Na narrativa, há relações de parentescos entre todos que compõem o grupo social, inicialmente formado a partir de um núcleo familiar. Possivelmente, este foi um dos fatores que possibilitaram a aglomeração dos posseiros na área de terra, mesmo tendo que enfrentar dificuldades de diversas naturezas. Esse fato pode ter contribuído também para o retorno de alguns que saíram à procura de emprego em fazendas distantes.

Outro aspecto importante no depoimento da entrevistada T.S.A., é a questão da necessidade de permanecer na terra e nela reproduzir o modo de vida, um fato que ocorre quando a identidade camponesa está presente. Isto pode ser percebido ao observar a trajetória daqueles que saíram da comunidade para ser vaqueiros em grandes fazendas no município e em pouco tempo retornaram para construir suas residências na comunidade Angical. Isso vai de encontro às ideias de Oliveira (2007), quando afirma que, às vezes, a migração é uma alternativa que os camponeses têm para ter acesso a terra. Neste processo percebe-se a dimensão do esforço dos camponeses para manter sua autonomia dentro das condições sociais do modo de vida da classe. 
Nos relatos dos idosos entrevistados é possível entender que a decisão de permanecer na determinada área parte da demanda que tinham de terra produtiva para morar e produzir. Com isso, muitos sacrifícios foram necessários, principalmente, pelos primeiros que chegaram, mas tendo como pretexto conseguir condições de reprodução social, sem ser explorados nas relações do trabalho assalariado vigentes nas fazendas. Além disso, alguns tentaram adaptar em outras terras e produzir na condição camponesa, mas não conseguiram condições de vida satisfatórias e retornaram. Podemos perceber isso nos relatos feitos por um dos camponeses mais antigos, de 80 anos, da comunidade Angical que foi entrevistado no povoado Bom Jesus das Palmas, para onde havia mudado recentemente:

Eu nasci e criei lá. Tanto que eu fiquei fora dalí não chegou três anos. Quando tava pra completar três anos eu ia voltando pra alí sozinho. Eu tava num lugar chamado Buriti. Mas lá só tinha necessidade e o gadinho era de cinco donos, três vendeu ficou só dois. E o Sarafim birrado lá. E aí eu fiquei quase três anos fora, voltei pro Angical denovo. Depois que eu voltei eles foram juntado. Foi primeiro Duca, depois foi Celino e foram juntando lá em roda até que ficou povoado. Mas esses mais velhos tudo deu certo. (N.R.A., PESQUISA DE CAMPO, 2017).

A adaptação destes camponeses no território que se formava ocorre em razão do grupo já ter chegado munido de saberes que permitiram a produção agrícola. Naquele período, de acordo com os depoimentos dos idosos da comunidade, não havia ainda problemas quanto à questão climática e havia disponibilidade de terras produtivas que não demandavam usos de recursos tecnológicos. Desse modo, o sucesso na produção de alimentos, mesmo com o emprego apenas técnicas tradicionais, foi uma das bases que sustentaram as famílias durante décadas. Nestes aspectos merece atenção a visão de Ariovaldo Umbelino de Oliveira, ao dizer:

O camponês é um dos tipos humanos que melhor realiza a relação homem natureza, pois dada sua perspectiva de produção da vida material e simbólica assume papel fundamental na constituição de diferentes modos de existência, na complexidade das relações sociais do mundo atual, especialmente sua capacidade de produção e reprodução cultural a partir de seus diferentes modos de reorganizar a vida e o trabalho, produzindo material e simbolicamente formas de existências que o colocam como parte de um processo social mais amplo na sociedade. (OLIVEIRA, 2001 b, p.182).

Foi em razão desta identidade com classe a que pertence, que os camponeses da comunidade Angical conseguiram estabelecer estratégias e organizar-se diante das condições sociais vigentes no momento que chegaram. O histórico de luta destes 
camponeses se caracteriza por diferentes períodos de resistências para conseguirem permanecer na terra e produzir os bens necessários à uma vida digna. Com isso, no período de ocupação e formação do território as dificuldades foram diferentes de outras que surgiram posteriormente.

Outro fator que possibilitou a permanência dos primeiros camponeses que chegaram no local foi a condição de acesso à terra que se dava sem haver qualquer conflito com possíveis donos da área. Os idosos da comunidade relatam que permaneceram algumas décadas sem serem perseguidos. Viviam em um ambiente de paz que motivava a luta contra as dificuldades de outras naturezas que eram obrigados a enfrentar.

Este cenário, de relativa paz no campo, só era possível porque no momento histórico em que o município de Paranã se encontrava a disputa por terra era menor. Mesmo sendo basicamente todas as terras do município já confiscadas por algum "proprietário" regular ou irregular, os posseiros conseguiam entrar para produzir sem haver conflitos, vistos que em alguns casos as terras se encontravam em situação de abandono e sob domínio do Estado. Sendo terras devolutas ou não, era possível haver a ocupação pacífica em grandes áreas improdutivas. Neste contexto, no cotidiano do camponês posseiro, às vezes, o principal problema enfrentado era a falta de vias de acesso à cidade, que sempre foi um espaço complementar das relações sociais desenvolvidas no campo.

No caso específico da comunidade Angical, a distância de 40 quilômetros da sede municipal, que era o centro urbano mais próximo, foi uma questão que demandou esforço no tráfego dos camponeses durante décadas, pois a necessidade de acesso a alguns recursos essenciais sempre exigiu o deslocamento para a cidade. $\mathrm{O}$ deslocamento até a cidade era caminhando ou a cavalos, que era o meio de transporte acessível. Neste período inexistência de estradas adequadas para o tráfego de veículo era uma realidade comum no município. Além disso, a frota de veículo existente não era suficiente para suprir a demanda até por volta dos anos 1990, pois apenas algumas pessoas da elite política e econômica possuíam automóvel. Com isso, a territorialização dos primeiros habitantes foi acompanhada de dificuldades que foram sendo superadas concomitantemente com o surgimento de outras.

Os problemas multiplicam com o advento da valorização das terras no município, principalmente a partir de 1980, momento em que surgem grandes latifúndios englobando 
áreas ocupadas historicamente por camponeses, sem os considerar no processo de delimitação. Assim, as famílias da comunidade Angical, existentes no momento da pesquisa, passam a viver um drama diferenciado das experiências que alguns dos seus antecedentes viveram. Elas lutam para resistir às forças expropriadoras e manter o controle sobre o território que se consolidou por meio de suas práticas sociais.

Com a expansão do capitalismo no campo a concentração da propriedade da terra se torna uma questão complexa, sobretudo no final do século XX quando cresce o número de grandes fazendeiros delimitando suas terras. O objetivo destes proprietários no município de Paranã, na maioria dos casos, nunca foi explorar a terra como um meio de produção e nem usá-la para explorar a força de trabalho. O foco foi ter a terra apenas como reserva de valor para vendê-la por altos preços no futuro. Trata-se de uma estratégia contraditória dentro do sistema capitalista, de tal modo que:

Esse é o motivo pelo qual quando o capitalista compra a terra não é porque
esteja, como senhor feudal, interessado na terra em si: o que ele efetivamente
compra é a renda da terra, o direito de se assenhoriar de uma parte da mais-
valia social. Neste sentido, a terra também é diferente do capital. Mesmo que
o proprietário não ponha sua terra para trabalhar, ainda assim ela lhe dará
direito de se apropriar de uma parte da riqueza socialmente produzida. Quando
o proprietário diz que sua terra está "valorizando" ele denuncia exatamente o
caráter irracional da propriedade fundiária: como pode a terra valorizar-se se
ela permanece improdutiva, se ela não incorpora trabalho, se não desenvolve
produto? (MARTINS, 1995, p. 166).

É com foco no lucro gerado através da venda da terra que os grandes proprietários avançam no processo de regularização de suas áreas causando a expropriação dos camponeses posseiros. Esta contradição se efetiva no município de Paranã de forma violenta em algumas fazendas, tendo trabalhadores rurais com suas casas destruídas no processo de desapropriação. Na comunidade Angical, de acordo com as entrevistas realizadas, frequentes ameaças tem sido a preocupação principal de todos os camponeses. No entanto, eles permanecem firmes na terra dispostos a lutar pela permanência definitiva no território.

Uma questão que deixa todos os camponeses em dúvida é a veracidade da documentação usada pelo fazendeiro para confirmar propriedade da terra. Tratando de uma área ainda considerada irregular, tendo sido apresentado apenas título paroquial como documento, segundo os posseiros, não é possível entender como se processaria a legalidade de um a eventual reintegração de posse. Assim, no momento da pesquisa, a 
questão da regularização parece apresentar impasses tanto para os camponeses como para o fazendeiro, que afirma ser proprietário das terras.

O histórico de regularização da comunidade Angical é uma questão emblemática. O que as famílias existentes sabem é que no início havia o pagamento de um "talão" (boleto) anual para o Estado como condição de permanência na terra. Entretanto, há muito tempo, por determinação do poder público, deixaram de pagar a referida taxa. Diversos camponeses relataram sobre isso, mesmo não sabendo decifrar de modo detalhado a natureza deste documento, do qual foi encontrado um exemplar, mas ilegível por estar deteriorado pelo tempo.

Surge, então, uma dúvida: Como poderíamos entender a relação dos posseiros diretamente com o órgão de controle do Estado sem haver o reconhecimento deles ao passar o poder das terras para um proprietário definitivo? É uma situação que nos leva a entender que possivelmente a aquisição da terra não tenha passado pelo devido processo legal nos órgãos públicos de controle fundiário. Com isso é possível compreender que a ocupação territorial e a resistência dos camponeses da comunidade Angical tem razão para existir desde o início.

A partir do momento em que os camponeses interromperam o pagamento das $\operatorname{taxas}^{4}$ anuais ao Estado os primeiros ocupantes desta área de terra e seus descendentes continuaram nela na condição de posseiros. O número de famílias foi crescendo, mas mantendo o uso coletivo da terra até por volta de 1990, quando começa a ocorrer a divisão da terra em pequenas "propriedades" familiar. A questão da regularização fundiária passa a ter uma nova fase. Se no início tratava-se de uma quitação com Estado, agora a documentação das posses tornou-se o foco principal para todos.

Os posseiros entendem que há possibilidade de regularização de suas áreas, entretanto, além dos conflitos com os fazendeiros, os custos em cartório são vistos como uma das dificuldades em razão da renda das famílias não favorecer esse processo. Dessa forma, o principal avanço que tem ocorrido na maioria dos casos é no que refere à demarcação e o georreferenciamento. No momento da pesquisa estes dois procedimentos

\footnotetext{
${ }^{4}$ Não foi possível decifrar, na íntegra, o teor da referida taxa, em razão de não haver documentos legíveis a respeito. Entretanto, foi visualizado um boleto da Secretaria da Fazendo do Estado de Goiás, de 1930, já deteriorado. De acordo com camponês que estava com o documento, um dos moradores mais antigos, tratava-se de um exemplar do talão fundiário que era pago ao Estado.
} 
já tinham sido realizados por alguns dos posseiros, pela a necessidade de ter o mínimo de segurança contra a invasão de suas áreas.

Figura 2 - Construção da cerca de um sítio na comunidade Angical

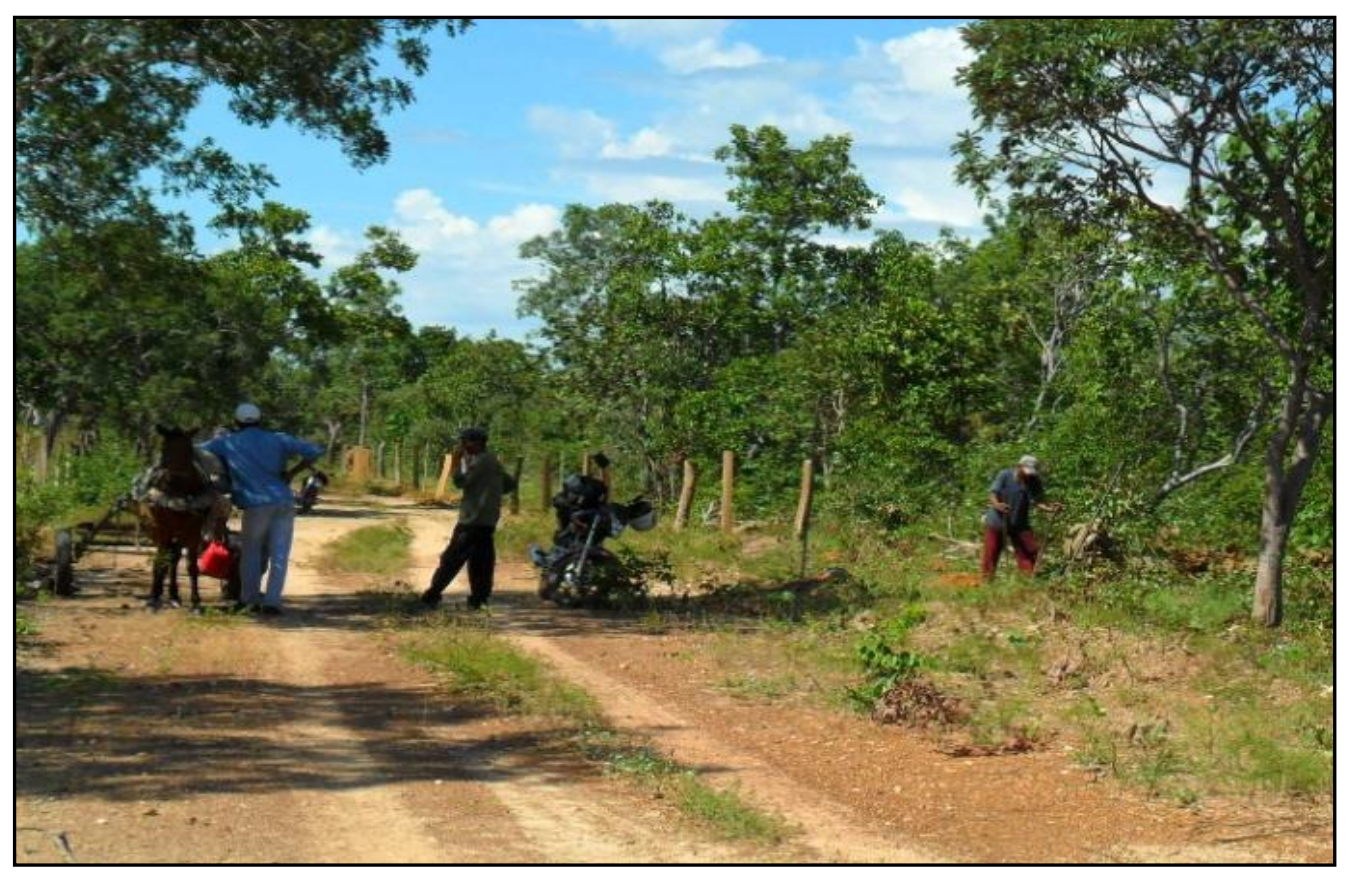

Fonte: Autor. TAVARES, 2017.

Com esta preocupação, o cercamento (figura 2) passa a ser uma necessidade para todos os membros da comunidade. Ao cercar as áreas de terra que os pertencem, os camponeses se consideram protegidos da entrada de pessoas estranhas, tendo mais domínio sobre a terra. Em razão disso, até mesmo as novas residências instaladas no interior da comunidade passaram a ter a construção de cerca como parte inicial da construção. Isso deixa claro o quanto se tornou forte a questão do domínio e da propriedade sobre a terra, mesmo pelos camponeses. A questão da demarcação territorial, no que refere à base material é bem intensa, pois a necessidade de controle sobre a posse individual é clara. $\mathrm{O}$ fato de a área ser conflituosa leva os posseiros à necessidade de fazer a delimitação de suas posses mesmo estando ainda pendentes quanto ao processo de regularização.

De acordo com as famílias entrevistadas, a regularização individual das posses tem sido uma questão complicada, por algumas razões bastante complexas. Primeiro porque o processo de demarcação das áreas pertencentes a cada família tem sido complexo, por falta de consenso. Segundo porque o custo para fazer a documentação é 
elevado, saindo do orçamento da maioria dos posseiros. E um terceiro motivo é o fato de haver fazendeiros e latifundiários também tentando regularizar toda a terra a seu favor, por dizer ser donos de uma grande área que engloba também a comunidade Angical.

Assim, a declaração de posse, emitida pelo Instituto de Colonização e Reforma Agrária (Incra), é o documento que quase todos possuem, o qual é usado em situações burocráticas enfrentadas no acesso às políticas públicas. Entretanto, em algumas situações este tipo de comprovação não é suficiente, como por exemplo, no caso de alguns financiamentos necessários para melhoria da produção agrícola. Desse modo, a falta de um documento definitivo vem sendo preocupante para as famílias em vários aspectos.

Diante destes impasses no processo de documentação, a vulnerabilidade do território acaba sendo maior quanto à perseguição de alguns grandes proprietários que vêm tentando organizar documentos para comprovar-se como proprietários definitivos das terras. Desse modo, uma grande preocupação dos camponeses da comunidade Angical é a regularização de suas posses de modo que possam ter mais segurança quanto à permanência na terra.

Outra dificuldade enfrentada na luta pela terra na comunidade Angical, sobretudo no processo de viabilização da regularização fundiária, é a falta de assistência jurídica aos camponeses. Foi possível perceber este fato nas conversas realizadas durante a pesquisa na comunidade. Entretanto, foi notável o início de uma força de mobilização mais conjunta para tentar resolver esta situação, pois a maioria das famílias percebem a luta pela terra como um objetivo do grupo e não apenas de alguns que são mais ameaçados.

Infere-se, então, que a ideia de sustentação do território está ligada ao controle dos posseiros sobre terra. Este fato está no centro dos conflitos enfrentados pela comunidade, tratando-se de uma luta de estrema necessidade para a existência do grupo. Esta importância é ainda maior quando o enfrentamento ocorre de modo coletivo, em que as diferentes famílias se organizam pela mesma causa. Isto estava ocorrendo no período da realização do campo da pesquisa, tendo como eventos marcantes a realização de reuniões tratando da questão dos conflitos agrários na comunidade.

Estas reuniões (figura 3) estavam ocorrendo para deliberar sobre a criação de uma associação dos camponeses da comunidade Angical ou o ingresso na Associação de 
Produtores Rurais Vale Areia ${ }^{5}$, que já estava consolidada e tendo, também, como objetivo a luta pelos interesses de posseiros, mas até então de outra região do município. Optaram pela segunda alternativa, com o proposto de unir as forças dos dois grupos de posseiros lutando pelo acesso e permanência na terra.

Figura 3 - Reunião dos camponeses da comunidade Angical

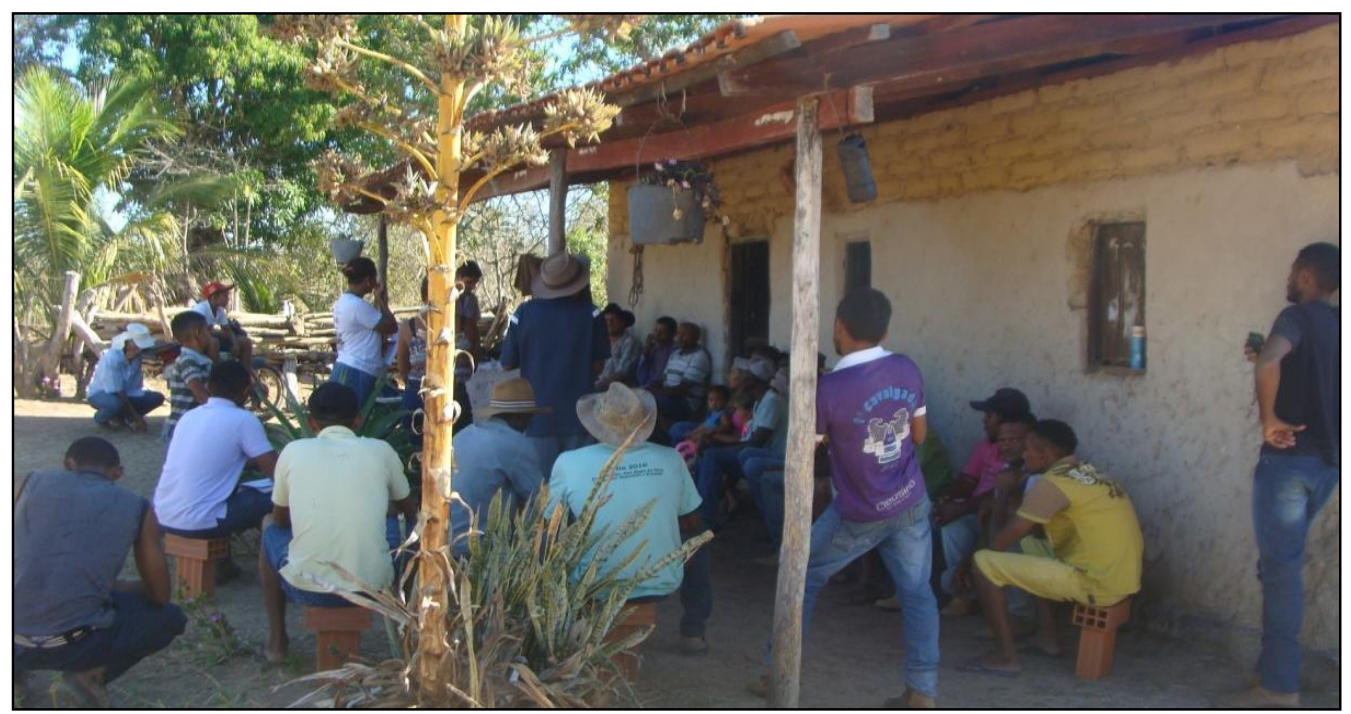

Fonte: Autor. TAVARES, 2017.

A iniciativa de associação que emerge em 2017 é um momento em que ocorre a articulação na comunidade com tais objetivos de lutar coletivamente pela terra. A intensificação das ameaças de fazendeiros provocou insegurança a ponto de os camponeses sentirem a necessidade de unir para lutar pelo território. Desse modo, a busca de legitimação dos seus direitos enquanto posseiros das terras que ocupam passa a ser o principal foco. Trata-se de mais um elemento de resistência, fruto das relações comunitárias entre as diferentes famílias.

Assim se processa a formação territorial e a sustentação da comunidade Angical frente aos conflitos agrários que enfrentam. A trajetória de luta dos camponeses permanece há mais de 100 anos, o que mostra a existência de uma resistência frente às forças capitalistas expropriadoras presentes no município de Paranã. Trata-se de uma luta

\footnotetext{
${ }^{5}$ A Associação de Produtores Rurais Vale Areia foi criada para reforçar a luta pela terra na ocupação realizada na proximidade da cidade de Paranã, na margem esquerda do rio Paranã. Entretanto a associação foi ampliada para outras áreas do município, tendo, inclusive, grande parte dos camponeses da comunidade Angical associados a partir de 2017.
} 
que as relações sociais presentes no campo exigem dos camponeses para permanecerem reproduzindo suas práticas sociais.

Ainda vale ressaltar que a realidade dos camponeses da comunidade Angical aproxima bastante das situações enfrentada por outros grupos no município de Paranã. Além disso, existem famílias de posseiros que não fazem parte de nenhuma comunidade, mas enfrentam problemas semelhantes para se manter na terra. O conflito entre camponeses e grandes proprietários é uma questão histórica em Paranã que parece se agravar nas últimas duas décadas, mas sem haver a devida intervenção do poder público, que seria o caminho de democratização do acesso a terra e diminuição da concentração fundiária.

\section{Considerações finais}

A existência e resistência do campesinato em Paranã se efetiva muito mais pelo protagonismo dos camponeses diante da necessidade de acesso e permanência na terra que pelas possibilidades de reprodução social que as relações presentes no campo garantem. Esta realidade está explícita no fato de a condição de posseiro, normalmente coagido pelos grandes "proprietários", ser a mais comum das formas de acesso à terra pelos camponeses no município. Assim, os conflitos agrários são permanentes em face da exclusão social que dificulta cada vez mais o acesso da terra aos camponeses enquanto os latifúndios, às vezes improdutivos, se sustentam.

Considerando os estudos teóricos e de campo realizados durante a pesquisa é possível entender que o processo de formação, e a permanência da comunidade Angical envolvem questões específicas de luta e resistência. Lutas que partem da necessidade de resistências às forças expropriadoras do território formado, ocupado e usado. Ou ainda, lutas oriundas das relações sociais cotidianas de cunho político, econômico e cultural e ambiental constituinte das práticas formadoras e transformadoras do espaço geográfico.

Sendo uma comunidade surgida no início do século XX, tem resistido a todas as forças antagônicas e ainda se reproduz no sentido de crescimento do número de famílias instaladas. Há diversos elementos de resistência identificados na análise do modo de vida consolidado por intermédio das práticas sociais vivenciadas. Uma conclusão desta investigação que chama muito atenção é o fato de a resistência camponesa não ocorrer por meio do isolamento, mas sim por estratégias de integração com outros espaços, 
havendo relações sociais internas e externas fundamentais para a permanência no território e, consequentemente, para a existência da reprodução social camponesa.

Os problemas relacionados à propriedade da terra é uma situação complexa, no caso dos camponeses posseiros da comunidade Angical. A convivência em meio de conflito com grandes fazendeiros tornou-se uma experiência duradoura que está no cerne da resistência da classe camponesa da qual grupo faz parte. A luta pela permanência na terra passa a ser uma questão que envolve o interesse coletivo do grupo e não mais uma situação relativamente tranquila como era antes da grande especulação pelas terras rurais do município. Assim foi possível perceber durante a pesquisa a iminência de melhor organização do grupo para lidar como os diversos problemas enfrentados na comunidade.

Desse modo, a formação e resistência da comunidade Angical por iniciativa da luta camponesa nos reporta à realidade mais ampla do município de Paranã quanto aos problemas agrários. O processo excludente de apropriação das terras do município criou as condições para tornarem necessários os conflitos existentes. Conflitos que possivelmente se resolveria de forma justa e democrática por meio de avanços na política de reforma agrária, diminuindo, também, outros problemas comuns no campo e na cidade.

\section{Referências}

ANDRADE, Manuel Correia de. A questão do território no Brasil. 2 ed. São Paulo: Hucitec, 2004.

BARBOSA, Messias Vieira. Reforma agrária no Tocantins: uma análise da luta e conquista da terra a partir do assentamento Paulo Freire I e II, Rio dos Bois - Tocantins. Dissertação (Mestrado em Geografia) Programa de Pós-Graduação em GeografiaPPGG - Universidade Federal do Tocantins, Porto Nacional -TO, 2016.

CUNHA, Pulo Ribeiro. Formoso e Trombas: a luta do partido e dos posseiros. 1995. Disponível em: <http://revistaprincipios.com.br/artigos/36/cat/1739>. Revista Princípios, Ed. 36. São Paulo: Fevereiro/Abril, 1995.

GUIMARÃES, Maria Tereza Canesin. Formas de organização camponesa em Goiás (1954/64). Goiania: Centro Editorial e Gráfico da UFG, 1988.

IBGE - Instituto Brasileiro de Geografia e Estatística. Censo Demográfico (2010). Disponível: <http://cidades.ibge.gov.br/xtras/temas.php?codmun=171620\&idtema=90>. Acesso em: 30 de marco de 2016.

MARTINS, José de Souza. Reforma agrária: o impossível dialogo. 1. ed. São Paulo: Edusp, 2004. 
Os camponeses e a política no Brasil. 5 ed. São Paulo: Vozes, 1995.

MIRANDA, Ricardo Ferreira; LIRA, Elizeu Ribeiro. A apropriação do campesinato pelo capitalismo rentista no Tocantins: o caso do Município de Miracema. In: SANTOS, Roberto de Souza (Org.). Território e diversidade territorial no Cerrado: projetos regionais, cidades e conflitos socioespaciais. Goiânia: Kelps, 2015. Cap. 12 p. 319-374.

MORAES, Antonio Carlos Robert de; COSTA, Wanderley Messias da. Geografia Crítica: a valorização do espaço. 4. ed. São Paulo: Editora Hucitec, 1999.

OLIVEIRA, Antônio Miranda de. Campesinato e identidade cultural no Tocantins. In: FREIRE, Juciley Silva Evangelista; OLIVEIRA, Antônio Miranda de (Orgs). Educação participação política e identidade cultural: uma contribuição multidisciplinar para a formação docente no Tocantins. Palmas TO: EDUFT, 2016. p.181-224.

OLIVEIRA, Ariovaldo Umbelino de. A longa marcha do campesinato brasileiro: movimentos sociais, conflitos e reforma agrária. Disponível em: <http://www.scielo.br/pdf/ea/v15n43/v15n43a15.pdf>. Estudos Avançados v.15, n.43 São Paulo: Set./Dez. 2001a.

Modo capitalista de produção, agricultura e reforma agrária. 1 ed. São Paulo: Labur Edições, 2007.

A agricultura camponesa no Brasil. 4 ed. São Pulo: Contexto, 2001b.

RAFFESTIN, Claude. Por uma Geografia do poder. São Paulo: Editora Ática S.A, 1993.

RIBEIRO, Ricardo Ferreira. Da largura ao cercamento: um balaço do programa de desenvolvimento do Cerrado. In: ZHOURI, Andréa; LASCHEFSKI, Klemens; PEREIRA, Doralice Barros (Orgs.). A insustentável leveza da política ambiental: desenvolvimento e conflitos socioambientais. Belo Horizonte: Autêntica, 2005.

SANTOS, Milton. Sociedade e Espaço: formação espacial como teoria e como método. 1982. Disponível em: <http://ricardoantasjr.org/wp-content/uploads/2013/05>. Acesso em: 15 de agosto de 2016

SANTOS, Roberto de Souza. Políticas públicas e agronegócio na Amazônia Legal: conflitos e contradições sociais no espaço agrário. In: SANTOS, et al. Território e diversidade territorial no Cerrado: projetos regionais, cidades e conflitos socioespaciais. vol. II. Goiânia: Kelps, 2015. p. 31-44.

Políticas públicas e agronegócio na Amazônia Legal/Cerrado: conflitos socioterritoriais. In: Olivera A. U. et al. Território em conflito, terra e poder. Goiânia: Kelps, 2014. Cap. 3, p. 171-226. 
SOUZA, Glaycon Vinícios Antunes de. Eventos sociais e naturais na constituição do front agrícola no MATOPIBA. XVIII Encontro Nacional de Geógrafos (A construção do Brasil: Geografia, ação política e democracia). Anais eletrônicos. São Luís/MA: 24 a 30 de julho de 2016. Disponível em: 〈http://www.eng2016.agb.org.br/resources/anais>. Acesso em 04 de Maio de 2017.

TOCANTINS. Governo do Estado. Instituto de Terras do Estado do Tocantins (Intertins). Diagnóstico Fundiário do Município de Paranã no Estado do Tocantins: relatório técnico final. Tomo I/V. vol. único. Palmas, 2010.

XAVIER, Glauber Lopes; SILVA, Mary Anne Vieira. Processos de acumulação capitalista e conflitos territoriais no cerrado. Cadernos Ceru v. 25, n. 2, 29 de maio de 2015. 